\title{
Mercury Leaching from Seafloor Massive Sulfide Deposits
}

\author{
AKINORI TAKEUCHI* ${ }^{*}$, SHIGESHI FUCHIDA ${ }^{2}$, AND \\ MASANOBU KAWACHI ${ }^{1123}$
}

"National Institute for Environmental Studies, 16-2

Onogawa Tsukuba-shi, Japan (*correspondence:

takeuchi.akinori@nies.go.jp)

22Waseda University, Japan (sfuchida@aoni.waseda.jp)

Evaluating potential environmental impacts of seafloor metal-mining is an important aspect in the natural resource exploitation. Seafloor massive sulfide depostis tend to contain a large amount of mercury $(\mathrm{Hg})$, one of the highly toxic elements, and it has been concerned about the $\mathrm{Hg}$ contamination occurs by accidental leakage and dispersion of sulfide ore particulates from mining vessels into the upper ocean. The potential $\mathrm{Hg}$ leaching into aerobic artifical seawater and phosphate buffer solution $(\mathrm{pH}=6.86)$ from 4 different hydrothermal ore deposits collected from the Okinawa Trough in Japan was investigated. $\mathrm{Hg}$ concentrations of the ore deposits ranged from approximately 7.5 to $658.5 \mu \mathrm{mol} / \mathrm{kg}$. The ore sample in which realgar (AsS) was barely identifed showed the highest amount of $\mathrm{Hg}$. The only pyrite (FeS)-rich ore sample ( $73 \mu \mathrm{mol} / \mathrm{kg}$ ), however, showed the $\mathrm{Hg}$ leaching into the seawater within 5-min by approximately $1.5 \%$ of the initial $\mathrm{Hg}$ conent in the ore sample. Both FeS-rich sample and the one with the highest $\mathrm{Hg}$ concentration, on the other hand, demonstrated the $\mathrm{Hg}$ leaching into the buffer solution within 5-min. The buffer solution also prompted more $\mathrm{Hg}$ leaching from the FeS-rich sample. Approximately $2.5 \%$ of the intial $\mathrm{Hg}$ content in the sample was detected in the solution. These results suggest that the $\mathrm{Hg}$ leaching from seafloor sulfide ore deposits occurs with specific mineral assemblage. Pyrite specially involves in the $\mathrm{Hg}$ release probably via mineral dissolution and generation of sulfate under aerobic aquatic condition. 